\title{
The State of the Planktonic and Benthic Components of the Ecosystem of the Golden Horn Bay (Peter the Great Bay, Sea of Japan) in the Area of the Coal Terminal
}

\author{
Elena Valerievna Smirnova ${ }^{1}$, Inga Vladimirovna Matrosova ${ }^{1 *}$ \\ ${ }^{1}$ Far Eastern State Technical Fisheries University, Engineering Disciplines Department, 52 B \\ Lugovaya Str., Vladivostok 690087, Russia
}

\begin{abstract}
Monitoring study of the state of the planktonic and benthic components of the ecosystem of the Golden Horn bay, Peter the Great Bay of the Sea of Japan in the area of the coal terminal was carried out in the autumn of 2020. Phytoplankton in the studied area was characterized by a depleted species composition. In September 2020, phytoplankton bloom was noted at the monitoring points, due to the massive development of diatom microalgae of the Chaethoceros genus, which accounted for $90 \%$ of the total phytoplankton. In November, the amount of phytoplankton was an order of magnitude lower, and the role of dinophytic algae increased in the community. Changes in the species composition and quantitative parameters of phytoplankton correspond to the seasonal dynamics in the eastern part of the Amursky bay, which is subject of anthropogenic pollution. Based on the study carried out, it can be concluded that the activities of the coal terminal in the Golden Horn bay had no effect on the structure of communities and, in general, there was no over-normative effect on the state of aquatic biological resources.
\end{abstract}

\section{Introduction}

The quality of natural water and its biological usefulness are mainly determined by the state of biohydrocenoses. The hydrobiological control system provides a direct assessment of the state of aquatic biocenoses, and this is its main advantage over other control and water quality systems. A comprehensive and full characterization of the state of the ecological system, the quality of its waters and bottom sediments is possible only on the basis of sufficiently complete data concerning the different aquatic communities. It is necessary to know the species composition of communities and quantitative indicators of populations of dominant and indicator species.

Under conditions of increasing anthropogenic pressure on marine ecosystems, the bottom and pelagic communities can undergo significant changes and even cardinal rearrangements. The pollution of bottom sediments and waters of the Golden Horn bay is at a level capable

* Corresponding author: Matrosova.IV@,dgtru.ru 
of causing the changes in bottom and pelagic communities [1, 2, 3, 4, 5, 6]. There is a need for a comprehensive study of the main parameters of the marine environment and ecosystems. Monitoring of the planktonic and benthic components of marine coastal ecosystems under anthropogenic impact caused by the coal terminal is an urgent task.

The goal of the monitoring work was to assess the state of the planktonic and benthic components of the ecosystem of the Golden Horn bay, Peter the Great Bay of the Sea of Japan in the area of the coal terminal of the commercial seaport in the autumn of 2020.

This goal required the following tasks to be solved:

- Collection and processing of samples of phyto- and zooplankton, macrobenthos at monitoring points.

- Laboratory processing of samples of zooplankton and macrobenthos.

- Assessment of the qualitative and quantitative indicators of phytoplankton, zooplankton, and macrobenthos at monitoring points.

\section{Research materials and methods}

The research was carried out in two stages: from September 23 to October 23, 2020 and from October 23 to November 23, 2020. Sampling of phytoplankton, zooplankton, and macrobenthos was carried out in the Golden Horn bay of the Peter the Great Bay, in the water area of the seaport at the following points. The first stage was in 250 meters directly from the wastewater outlet towards the sea ( 1 station, the depth was $15 \mathrm{~m}$ ) and 480 meters to the right of the wastewater outlet towards the sea ( 2 station, the depth was $17 \mathrm{~m}$ ). The second stage was in 250 meters directly from the wastewater outlet water towards the sea (1 station, depth $25 \mathrm{~m}$ ) and 480 meters to the right of the wastewater outlet towards the sea (2 station, depth $20 \mathrm{~m})$.

The location of the sampling points during the monitoring was determined using the onboard GPS system.

The study was carried out according to standard hydrobiological methods [7-11]. The species composition and dynamics of quantitative indicators of phyto- and zooplankton, macrobenthos were estimated. During the survey, 6 phytoplankton samples, 4 zooplankton samples, and 4 macrobenthos samples were taken and processed during the first stage; during the second stage - 4 samples of plankton and 6 samples of macrobenthos were processed.

Samples of phyto- and zooplankton were taken in total, the water column was caught from the surface to the bottom. A Judy net with a $37 \mathrm{~cm}$ inlet diameter and a gas filtering cone No. 59 were used. The samples were fixed in a $4 \%$ formalin solution.

The sampling of plankton was carried out simultaneously with the sampling of sea water at the points of the observation network. Phytoplankton samples were taken from the surface to the bottom with a Molchanov bathometer. Simultaneously with the sampling of plankton, the water temperature was measured.

Zooplankton samples were taken in total, the water column was caught from the surface to the bottom. A Judy net with a $37 \mathrm{~cm}$ inlet diameter and a gas filtering cone No. 59 were used. Samples were fixed in 10\% formalin solution

Samples of macrobenthos were taken using a bottom grab with a capture area in the first stage of research $-0.25 \mathrm{~m}^{2}$, in the second stage $-0.1 \mathrm{~m}^{2}$ ( 3 samples at the station), from the vessel board. The samples were washed on board of the vessel through a sieve with a mesh of $1 \mathrm{~mm}$; macrozoobenthos organisms were fixed with $10 \%$ formaldehyde buffer solution. The wet weight was determined on a pharmacy and torsion balance. Before weighing, the animals were dried on filter paper for one minute.

In each benthic sample, the species composition was determined for each species and systematic group to which it belongs (order rank of detachment - class, order), the number of organisms (ind. $\left./ \mathrm{m}^{2}\right)$ and biomass $\left(\mathrm{g} / \mathrm{m}^{2}\right)$ were determined. The wet weight was determined 
on an electronic balance with an accuracy of $0.001 \mathrm{~g}$. Before weighing, the animals were dried on filter paper for one minute.

For all components of the ecosystem (phytoplankton, zooplankton, and macrobenthos), the following statistical characteristics were determined from the studied monitoring points: average total biomass and average total population density, average biomass and population density of the main groups and main species. In addition, the total number and the average number of species were counted.

Cameral processing of samples was carried out in the laboratory. Under processing the plankton samples, the taxonomic composition was determined, and the common species of phyto- and zooplankton were identified. The density of the settlement was assessed, and the dominant species were identified. The dominance of a species was understood as a proportion of at least $20 \%$ of the total number of organisms.

\section{Research results}

\subsection{Monitoring of biological characteristics of marine pelagic and benthic communities in September 2020}

Plankton. Tracking the changes in plankton is one of the methods of hydrobiological monitoring of polluted waters.

The phytoplankton composition at the surveyed monitoring points was dominated by diatoms, the total abundance of which was $96-99 \%$ of the total phytoplankton abundance. At the time of collecting the material, a massive development of diatoms of the genus Chaethoceros was observed at the monitoring points. The concentration was 0.5 million cells/L at point 1 and 0.32 million cells/L at point 2 . Species of the genus Chaethoceros were among the common phytoplankton species in the coastal waters of Peter the Great Bay in the summer-autumn period. The second place in terms of density was occupied by the heterotrophic dinophytic alga Nocteluca sp. The mass development of species of the genus Nocteluca is characteristic of the eutrophied areas of the Peter the Great Bay.

The zooplankton contained copepods, cladocerans, chaetomaxillary, hydroid jellyfish, amphipods, and larvae of bivalve molluscs and polychaetes. In total, in the surveyed points, 10 species and taxa of invertebrates of the supraspecific rank of animals were found (Table 1). The main mass of zooplankton was made up of small copepods Oithona similis (1600 ind. $/ \mathrm{m}^{3}$ ), the second was cladocerans Pogon leucartii. The share of meroplankton was $20 \%$ of the total number of zooplankton. At point 2, the number of invertebrate larvae was higher.

Table 1. Species composition and quantitative indicators of zooplankton at monitoring stations.

\begin{tabular}{|c|c|c|}
\hline & Station 1 & Station 2 \\
\hline Zooplankton groups & Density (ind. $/ \mathrm{m}^{3}$ ) & Density (ind. $/ \mathrm{m}^{3}$ ) \\
\hline Copepoda & 160 & 190 \\
\hline Cladocera & 60 & 50 \\
\hline Tintinnidae & 20 & 10 \\
\hline Chaetognatha & 12 & 22 \\
\hline Meroplankton & 40 & 380 \\
\hline Total & 292 & \\
\hline
\end{tabular}


Macrobenthos. The studied areas were characterized by sandy-pebble soils. There was no phytobenthos in the study area.

Representatives of 6 groups of invertebrates were found in the macrobenthos: polychaetes, amphipods, nemerteans, ophiuras, and starfish (Table 2).

Table 2. Species composition and quantitative indicators of macrobenthos at monitoring stations.

\begin{tabular}{|c|c|c|c|c|}
\hline \multirow{2}{*}{ Species } & \multicolumn{2}{|c|}{ Station 1 } & \multicolumn{2}{c|}{ Station 2 } \\
\cline { 2 - 5 } & $\begin{array}{c}\text { Density, } \\
\mathrm{g} / \mathrm{m}^{2}\end{array}$ & $\begin{array}{c}\text { Biomass, } \\
\mathrm{g} / \mathrm{m}^{2}\end{array}$ & $\begin{array}{c}\text { Density, } \\
\mathrm{g} / \mathrm{m}^{2}\end{array}$ & $\begin{array}{c}\text { Biomass, } \\
\mathrm{g} / \mathrm{m}^{2}\end{array}$ \\
\hline Algae & 0 & 0,00 & 0 & 0,00 \\
\hline Polychaeta & 14 & 11,00 & 44 & 15,00 \\
\hline Schistomeringos japonica & 9 & 5,00 & 2 & 0,00 \\
\hline Nereis vexillosa & 1 & 0,10 & 0 & 0,00 \\
\hline Nemertini & 10 & 0,003 & 0 & 0,00 \\
\hline Cumacea & 4 & 0,040 & 0 & 0,00 \\
\hline Amphipoda & 4 & 0,52 & 10 & 0,88 \\
\hline Gastropoda & & & & \\
\hline Thapsiella plicosa & 100 & 2,00 & 72 & 2,10 \\
\hline Phoronidae & & & 2 & 5,811 \\
\hline Phoronopsis harmeri & & & 1 & 40,00 \\
\hline Ophiuroidea & 158 & 18,66 & 129 & 63,00 \\
\hline Asteroidea & & & & \\
\hline Total & & & & 0 \\
\hline
\end{tabular}

Bottom communities in the surveyed points were characterized by low biomass values (Table 2). The biomass of macrozoobenthos was $60 \mathrm{~g} / \mathrm{m}^{2}$ at point 1 and $18.6 \mathrm{~g} / \mathrm{m}^{2}$ at point 2 . The dominant taxa of macrozoobenthos were polychaetes and phoronids. Among the dominant species were noted polychaetes and phoronids $\mathrm{Ph}$. Harmeri; the higher biomass at point 2 was due to the presence of starfish.

\subsection{Monitoring of biological characteristics of marine pelagic and benthic communities in November 2020}

Plankton. The phytoplankton concentration at the surveyed monitoring points at the second stage of research was 0.45 million cells/L at point 1 and 0.39 million cells/L. at point 2 .

The phytoplankton was dominated by diatoms, the total abundance of which was $68 \%$ of the total phytoplankton abundance. The dominant diatom species included organic pollution indicator species Sceletonema costatum and Thalassionema nitzschioides (Table 3).

Dinophytic algae were in second place in terms of density. Among planktonic dinoflagellates, the representatives of the main orders of dinophytic algae were found: Prorocentrales, Dinophysiales, Gymnodiniales, and Peridiniales. All marked species are massive.

The dominant species included Nocteluca scintillans. The mass development of species of the genus $N$. scintillans is characteristic of the eutrophied areas of the Peter the Great Bay.

Table 3. Phytoplankton composition and density (thousand cells/L) at monitoring stations.

\begin{tabular}{|c|c|c|}
\hline Species & Station 1 & Station 2 \\
\hline
\end{tabular}




\begin{tabular}{|c|c|c|}
\hline \multicolumn{3}{|l|}{ Order Bacillariophyta } \\
\hline Chaetoceros affinis & 43620,21 & 31625,2 \\
\hline Chaetoceros decipiens & 8420,15 & 3126,86 \\
\hline Chaetoceros compressus & 16846,28 & 4121,15 \\
\hline Chaetoceros debilis & 30121,34 & 40145,9 \\
\hline Leptrocylindrus dacinus & 2127,92 & 6181,32 \\
\hline Eucampia zoodiacus & 28234,12 & 13539,2 \\
\hline Thalassionema nitzschioides & 50142,14 & 54512,2 \\
\hline Thalassiosira nordenskioeldii & 12526,31 & 2482,12 \\
\hline Sceletonema costatum & 15142,12 & 3841,45 \\
\hline Subtotal & 3111878,42 & 237551,42 \\
\hline \multicolumn{3}{|l|}{ Order Euglenophyta } \\
\hline Eutreptia lanowii & 9789,47 & 1186,15 \\
\hline \multicolumn{3}{|l|}{ Order Dynophyta } \\
\hline Gonyaulax diegensis & 224142 & 193420 \\
\hline Protoperidinium pyriforme & 22321,33 & 1239,87 \\
\hline Dinophysis acuminata & 6315,78 & 8279,43 \\
\hline Noctiluca scintillans & 15479,1 & 2987,44 \\
\hline Gyrodinium lachrima & 13789,59 & 20152,2 \\
\hline Subtotal & 127102,1 & 148102 \\
\hline Total & 448669,18 & 386840,6 \\
\hline
\end{tabular}

The share of euglena algae Eutreptia lanowii was significant - $15 \%$ of the total density. The presence of euglena is characteristic of warm, eutrophied waters, which include the water area of the Golden Horn bay.

The zooplankton included copepods, cladocerans, chaetomaxillus, tunicates, larvae of bivalve molluscs and polychaetes, and barnacles. In total, in the surveyed points, 9 species and taxa of invertebrates of supraspecific rank were found (Table 4).

Table 4. Composition and quantitative indicators of zooplankton at monitoring stations.

\begin{tabular}{|c|c|c|}
\hline & Station 1 & Station 2 \\
\hline Zooplankton groups & Density (ind. $\left./ \mathrm{m}^{3}\right)$ & Density (ind. $/ \mathrm{m}^{3}$ ) \\
\hline Copepoda & 617 & 1081 \\
\hline Cladocera & 77 & 50 \\
\hline Chaetognatha & 12 & 22 \\
\hline Tunicata & 5 & 18 \\
\hline Meroplankton & 45 & 106 \\
\hline Total & 832 & 1277 \\
\hline
\end{tabular}


During the period of study, holoplankton played a leading role in the zooplankton at monitoring points, accounting for $87 \%$; meroplankton accounted for $13 \%$ of the total zooplankton density. At point 2 , the number of invertebrate larvae was higher. A similar ratio of taxonomic groups was quite often observed in the coastal zone of temperate latitudes in the autumn period.

The main mass of zooplankton was made up of small copepods Oithona similes and Acartia slausi (215 ind. $/ \mathrm{m}^{3}$ and $160 \mathrm{ind} . / \mathrm{m}^{3}$, respectively); the cladocerans Rogon leucartii were in second place in terms of density.

Macrobenthos. The soil at the monitoring points was mixed, silty-pebble. Alleurites with the smell of hydrogen sulfide and hydrocarbons, unrolled pebbles, and coal slag were present. There was no phytobenthos in the studied area.

Representatives of 6 groups of invertebrates were found in the macrobenthos: bivalve mollusks, ascidians, hydroids, polychaetes, phoronids, and nemertines (Table 5).

Table 5. Species composition and quantitative indicators of macrobenthos at monitoring stations.

\begin{tabular}{|c|c|c|c|c|}
\hline & \multicolumn{2}{|c|}{ Station 1 } & \multicolumn{2}{c|}{ Station 2 } \\
\hline Species & Density, & Biomass, & Density, & Biomass, \\
\hline Algae & ind./m & $\mathrm{g} / \mathrm{m}^{2}$ & ind. $/ \mathrm{m}^{2}$ & $\mathrm{~g} / \mathrm{m}^{2}$ \\
\hline Hydrozoa & 0 & 0 & 0 & 0 \\
\hline Obellia longissima & 3 & 0,001 & 0 & 0 \\
\hline Polychaeta & & & & \\
\hline $\begin{array}{c}\text { Schistomeringos } \\
\text { japonica }\end{array}$ & 14 & 11 & 44 & 15 \\
\hline Nereis vexillosa & 3 & 15 & 2 & 0 \\
\hline Nemertini & 1 & 0,2 & 0 & 0 \\
\hline Bivalvia & & & & 0,88 \\
\hline Telenidae & 4 & 0,52 & 10 & \\
\hline Phoronidae & & & & 17,7 \\
\hline Phoronopsis harmeri & 70 & 1,4 & 28 & \\
\hline Ascidia & & & & \\
\hline Bolteniaechiniata & 0,3 & 9 & & \\
\hline Total & 95,3 & 37,62 & & \\
\hline
\end{tabular}

Bottom communities in the surveyed points were characterized by low biomass values (Table 5). The biomass of macrozoobenthos was $37.6 \mathrm{~g} / \mathrm{m}^{2}$ at point 1 and $17.6 \mathrm{~g} / \mathrm{m}^{2}$ at point 2. The dominant taxa of macrozoobenthos were polychaetes and phoronids. Among the dominant species were polychaetes and phoronids $P h$. harmeri.

Attached organisms - ascidians and hydroids - were noted on fragments of coal slag.

Thus, the information obtained is consistent with the literature data. Pollution leads to changes in indicators that determine species diversity. Under the influence of pollution, a redistribution of dominants takes place. Several tolerant species begin to predominate in the community, reaching the abnormally high numbers, while the more sensitive ones become 
rare and disappear. Under conditions of increasing the anthropogenic pressure on marine ecosystems, bottom and pelagic communities can undergo significant changes, and even cardinal rearrangements. The increasing level of pollution of the marine environment and the formation of substrates typical for polluted semi-enclosed water areas have led to serious changes in the structure of communities in the Golden Horn bay [1, 2, 3, 4, 5]. Benthos species with a long life cycle, sensitive to pollution, are replaced by short-cycle tolerant organisms.

Phytoplankton in the Golden Horn bay in the area of the commercial seaport in autumn was characterized by a depleted species composition and the presence of indicator species of eutrophied waters. In September, an increased concentration of diatom microalgae of the genus Chaethoceros was noted. Species of the genus Chaethoctros are among the common phytoplankton species in the coastal waters of the Peter the Great Bay in the summer-autumn period. In November, the organic pollution indicator species Sceletonema costatum and Thalassionema nitzschioides dominated. In second place in terms of density was the heterotrophic dinophytic alga Nocteluca sp. The mass development of species of the genus Nocteluca is characteristic of the eutrophied areas of the Peter the Great Bay.

In the composition of zooplankton, both in September and in November, forms typical of the autumn complex of the coastal zone of the Peter the Great Bay were noted. The planktonic community was dominated by stenobiont forms.

The soil at the monitoring points during the study period was mixed: sandy-pebble and silty-pebble. Alleurites with the smell of hydrogen sulphide and hydrocarbons, rough pebbles, and coal slag were present in November. There was no phytobenthos in the studied area.

The examined samples of macrobenthos in September were dominated by the species resistant to pollution, noted in the Golden Horn bay earlier. In November, sessile sestonfeeders were present on fragments of hard soil, which may indirectly indicate an insignificant content of inorganic suspended matter in the bottom water layers.

\section{Conclusions}

Currently, there is a need for a comprehensive study of the main parameters of the marine environment and ecosystems of seaports by monitoring the planktonic and benthic components. The specificity of planktonic and benthic communities has been analyzed in sufficient detail by many authors [11-34].

The Golden Horn bay is one of the most polluted waters of the Peter the Great Bay. Changes in the composition of plankton and benthos, noted in the bay, are expressed in the reduction of some species, mainly due to the influence of pollution. These changes are reflected in a decrease in benthos biomass; reduction of the ranges of some species of echinoderms, molluscs, and polychaetes; the disappearance of certain species of animals; the emergence of new biocenoses with dominant species of polychaetes and phoronids $[3,2,12]$.

Regular hydrobiological observations in the water area of the Vladivostok port began in the mid-1970s. at the stations of the National Service for Observation and Control (NSOC). However, these data were practically not published.

In the Amursky bay during the late 20th - early 21 st centuries, pollution and siltation developed most intensively in the eastern part of the bay, i.e. in the zone of influence of waste water of Vladivostok. New communities, resistant to siltation and pollution, have appeared. Dead zones without bottom population were found in the Golden Horn and Nakhodka bays [24-26].

The phytoplankton of the Golden Horn bay contains 76 species of diatoms, dinophytes, golden and euglena microalgae. A specific feature of the summer and autumn complexes of the Golden Horn bay was the predominance of flagellated microalgae, the total abundance of 
which was $51-77 \%$ of the total phytoplankton abundance [5]. The basis of the community was formed by 22 species of microalgae, the share of which was at least $90 \%$ of the total number. In the Golden Horn bay maximum density of phytoplankton was noted in June (1.7 million cells/L), dominated by "small flagellate" algae (45.5\%). The predominance of the flagellated community of microalgae over the diatom was traced in the summer-autumn period in the Golden Horn bay (20 to 82\%). Euglena (Eutreptiella gimnastica Throndsen) and green (Pyramimonas sp.) algae reached their maximum density, which indicates a high level of organic pollution of the bay.

The density of microalgae varied from 60 thousand to 30 million cells/L. During the period of study, there were two peaks in abundance: at the end of April and in August. A similar seasonal dynamics was previously noted in the eutrophied part of the Amursky bay [7].

When studying the zooplankton in the Sea of Japan, the focus has always been on the neritic zone. Parasagitta elegans, Neocalanus plumchrus, Pseudocalanus minutus, Metridia pacifica, Oithona similis, Neocalanus cristatus, were usually named among the first ten species in terms of biomass. The second ten species (by biomass) included Paracalanus parvus, Clione limacina, Pareuchaeta japonica, Mesocalanus tenuicornis, Tortanus discaudatus, Clausocalanus arcuicornis, etc. [2, 8, 29, 30].

Small short-cycle species prevail in the coastal waters of the Peter the Great Bay. Zooplankton here more quickly "responds" to phytoplankton outbreaks. In such situations, it is legitimate to speak of a well-defined autumn peak in numbers. The basis of zooplankton is made up of copepods, chaetomaxillary, larvae of benthic invertebrates; a characteristic feature of nonretic zooplankton is the presence of copepods [8, 9].

Since the second half of the 20th century, in the eastern part of the Amursky bay, including the Golden Horn bay, there has been a reduction in the areas of Echinoidea, Ophiuroidea, Asteroidea, Bivalvia. Due to the silting of the bottom, there is less substrate for the settling of invertebrate larvae. Arca boucardi increased among bivalve mollusks in the eastern part of Amursky bay [3].

In the Golden Horn bay, the average biomass of benthos is on average only $82 \mathrm{~g} / \mathrm{m}^{2}$, and of bivalve molluscs - $10 \mathrm{~g} / \mathrm{m}^{2}$ (about $8 \%$ ). Outside this zone, these indicators were 154.7 $\mathrm{g} / \mathrm{m}^{2}$, of which $46.4 \%$ were bivalve mollusks [1].

The benthos of the water area is characterized by low biomass values of the diversity index, but a high population density, which was created due to the massive development of ecologically plastic species with a short life cycle and high rates of reproduction, called positive indicators of pollution. These include: polychaetes Th. pacifica, C. capitata, Sch. japonica, D. cardalia, C. cirratus, Ch. cincta, Ch. setosa and phoronid Ph. harmeri. Species sensitive to pollution, called negative indicators of pollution, are polychaetes M. sarsi, S. inflatum, S. bassi, S. armiger, S. bombyx, L. cirrata, P. praetermissa, bivalve mollusks A. subquadrata, R. pulchella, C. adamsi, A. ojianus, ophiura O. sarsi, O. kinbergi, A. fissa. In an area with moderate and low pollution, the biomass increased to $110 \mathrm{~g} / \mathrm{m}^{2}$. In the direction towards the "cleanest" area, there was an increase in biomass and a decrease in the population density of benthic animals. In the area of extremely high pollution, the lowest number of faunistic groups was noted (11), of which the group of polychaete worms dominated, accounting for more than $70 \%$ of the total number of benthos. Phoronids, bivalves, and gastropods made up $9 \%$ each. The remaining seven groups account for $2 \%$. The maximum number of groups (22) was found in the zone of moderate and low pollution. Polychaetes did also prevail here, but their share decreased to $58 \%$, while the amount of bivalve molluscs, echinoderms, and crustaceans was increasing [1].

Average biomass of benthos in the eastern part of the Amursky bay. $\left(90 \mathrm{~g} / \mathrm{m}^{2}\right)$ in the mid2000 s was almost two times less than in the $70 \mathrm{~s}$, and the diversity index in most of the water area was low $[1,4]$. 
To date, the increasing level of pollution of the marine environment and the formation of substrates typical for polluted semi-enclosed water areas have led to serious changes in the structure of communities in the Golden Horn bay. Long-lived benthos species sensitive to pollution have been replaced by short-cycle tolerant organisms, and taxonomic and species diversity has declined sharply.

As a result of our research, we came to a conclusion. Phytoplankton in the Golden Horn bay in the area of the commercial seaport in the zone of the coal terminal was characterized by a depleted species composition. At the first stage of research, in September 2020, phytoplankton bloom was noted at the monitoring points, due to the massive development of diatom microalgae of the genus Chaethoceros, which accounted for $90 \%$ of the total phytoplankton. At the second stage, the amount of phytoplankton was an order of magnitude lower, and the role of dinophytic algae in the community increased. The change in the species composition and quantitative indicators of phytoplankton in the study area, in general, corresponds to the course of seasonal dynamics in the eastern part of the Amursky bay, which is a subject to anthropogenic pollution.

The zooplankton contained forms typical for the autumn-summer (in September) and autumn (in November) zooplankton complex in the coastal zone of the Peter the Great Bay. Zooplankton, with a sufficient abundance of phytoplankton, was characterized by low qualitative and quantitative indicators. The proportion of benthic invertebrate larvae was $10 \%$ in September and 15\% in November. The plankton community was dominated by eurybiontic forms capable of withstanding the effect of pollution.

Analysis of macrobenthos samples showed that the biotope at station 1, located in $250 \mathrm{~m}$ from the outlet, was mixed soil, including silt with the smell of hydrogen sulfide and hydrocarbons and stones; at station 2, in $480 \mathrm{~m}$ from the outlet, coarse sand and broken shells did prevail, also with the smell of hydrogen sulfide.

The macrobenthos at station 1 was characterized by a large number of species, the presence of starfish and ascidians. Attached forms were noted on fragments of hard ground. The presence of ascidians may indirectly indicate an insignificant content of inorganic suspended matter in the bottom layers of water. Small invertebrates - polychaetes and phoronids dominated at Station 2. The examined samples of macrobenthos were dominated by the species resistant to pollution, characteristic of the macrobenthos of the Golden Horn bay.

Phytoplankton, zooplankton, and macrobenthos atf the monitoring stations of the commercial seaport in the area of the coal terminal were similar in species composition and quantitative parameters to the biota of other parts of the Golden Horn bay and the polluted waters of the Peter the Great Bay. The state of the planktonic and benthic components of the ecosystem at the monitoring points corresponded to the state of the biota exposed to hydrocarbon and organic pollution.

Based on the study carried out, it can be concluded that the activities of the seaport in the Golden Horn bay in the zone of the coal terminal had no effect on the structure of communities and, in general, no excess effect on the state of aquatic biological resources was found.

\section{References}

1. A.V. Tkalin, Assessment of the state of the marine environment in the Vladivostok area by the content of pollutants in mollusks and soils. Hydrometeorological Processes on the Shelf: Assessment of Impact on the Marine Environment. DVNIGMI Bulletin, 114124 (1998) 
2. A.A. Ogorodnikova, Ecological and economic assessment of the impact of coastal pollution sources on the natural environment and biological resources of the Peter the Great Bay. TINRO-center Bulletin, 193 (2001)

3. T.A. Belan, Belan L.S., Berezov A.V. Marine Biology and Ecology, 119-127 (2009)

4. V.P. Shuntov, Biology of the Far Eastern seas of Russia. TINRO Center Bulletin, 1, 580 (2001)

5. A.A. Begun, Algology, 16 (4), 417-434 (2006)

6. A.A. Begun, TINRO Center Bulletin, 163, 240-285 (2010)

7. A.F. Volkov, TINRO Center Bulletin, 154, 405-416 (2008)

8. A.F. Volkov, TINRO Center Bulletin, 119, 306-311 (1996)

9. T.I. Koltsova, Konoplya L.A., Maksimov V.I., Fedorov V.D. Hydrobiol. Journal, 7 (3), 109-117 (1971)

10. Guidelines for the methods of biological analysis of seawater and bottom sediments. Hydromet. Publ., 239 (1983)

11. V.A. Nadtochiy, Budnikova L.L., Bezrukov R.G. TINRO Bulletin, 140, 170-195 (2005)

12. T. Falkenhaug, Polar Res, 10 (2), 487-506 (1991)

13. B.W. J. Frost, Zool., 67, 525-551 (1989)

14. S. Hayashi, Hirakawa K. Bull. Jap. Sea Natl. Fish. Res. Inst., 47, 57-66 (1997)

15. K. Hirakawa, Bull. Plankton Soc. Jap. (Spec. Vol), 373-382 (1991)

16. K. Hirakawa, Imamura A. Seasonal abundance and life histiry of Metridia pacifica (Copepoda: Calanoida) in Toyama Bay, southern Japan Sea. Ibid, 40 (1), 41-54 (1993)

17. K. Hirakawa, Ogawa Y. Characteristics of the Copepod Assemblage in the Southwestern Japan Sea and its implication for Anchovy population dynamics. Ibid, 46, 45-64 (1996)

18. T. Ikeda, Hirakawa K., Kajihara N. Some characteristics of a coldwater copepod Calanus cristatus from regions of the Japan Sea covered by the Tsusima warm. Ibid, 40, 51-65 (1990)

19. G.S. Kleepel, Holliday D.V., Pierer R.E. Limnol. and oceanogr, 36 (1), 172-178 (1991)

20. I.A. McLaren, J. Res. Board Canada, 20 (3), (1963)

21. C.B. Miller, Frost B.W., Batchelder H.P. et al. Life history of large, grazing copepods in a subarctic ocean gyre: Neocalanus cristatus and Eucalanus bungii in the Northeast Pacific. Prog. Oceanogr, 13, 201 -243 (1984)

22. S. J. Nagasawa, Plankton Res, 11 (3), 615 - 618 (1989)

23. T.N. Dolganova, TINRO Bulletin, 128, 810-889 (2001)

24. D.I. Vyshkvartsev, Kryuchkova N.A., Karapetyan T.Sh. Zooplankton studies in shallow bays of Posiet Bay in 1969-1971. Research of pelagic and benthic organisms of the Far Eastern seas, 15, 17-29 (1979)

25. N.T. Dolganova, Nadtochiy V.V. TINRO Bulletin, 181, 169- 190 (2015)

26. N.T. Dolganova, Mesoplankton distribution in the West Japan Sea. PICES. Scientific Report (6). - Proceeding of the workshop on the Okhotsk Sea and adjacent areas, 318324 (1996)

27. N.T. Dolganova, Hirakawa K., Takahashi T. Bull. Japan Sea Natl. Res. Inst, 49 (1999)

28. Implementation of fishery monitoring for the study and resource research of aquatic biological resources and their habitat during the current repair of the prism of berth No. 13 of PJSC "VMCP". Research report of "VNIRO" (TINRO), 50 (2020)

29. N.V. Kolpakov, et al. Ecosystem studies of bioresources of coastal and estuarine waters of southern Primorye. TINRO-85. Results of ten years of activity. 2000-2010 TINROCenter, 103-128 (2010)

30. Stonik I.V., Orlova T.Yu. Marine Biology, 24 (4), 205-211 (1998)

31. Species composition and quantitative distribution of diatoms of the genus Pseudonitzschia N. Peragallo, 1900 in the Russian waters of the Seas of Japan and Okhotsk. Marine Biology, 39 (4), 246-253 (2013) 
32. O.G. Shevchenko, Orlova T.Yu., Maslennikov S.I. Marine Biology, 30 (1), 30-38 (2004)

33. P. Andersen, Throndsen O. Estimating cell numbers. Manual on Harmful Marine Microalgae / Eds. Hallegraeff G.M., Anderson D.M., Cembella A.D. Paris: UNESCO Publishing, 99-129 (2003)

34. I.V. Stonik, Orlova T.Yu. Ocean and Polar Research, 24 (4), 359-365 (2002) 